\title{
Edukasi Kesehatan Reproduksi dan Yoga pada Remaja di Sekolah Menengah Kesehatan Sadewa Yogyakarta Budi Rahayu,,$^{1, *}$ Melisa Putri R., ${ }^{2}$ Nendhy Wahyunia Utami, ${ }^{3}$ \\ 1,2,3,Kebidanan, Fkes Universitas Jenderal Achmad Yani, Yogyakarta, Indonesia e-mail: *1budiayu_88@yahoo.co.id
}

\begin{abstract}
ABSTRAK Masa remaja merupakan salah satu periode dari perkembangan manusia. Masa ini adalah masa yang penuh gejolak, masa yang penuh dengan berbagai pengenalan dan petualangan akan hal-hal baru sebagai bekal untuk mengisi kehidupan mereka kelak. Sayangnya, banyak remaja yang tidak sadar bahwa beberapa pengalaman yang tampaknya menyenangkan justru dapat menjerumuskan. Akibat emosi yang masih labil, tidak sedikit remaja terjerumus dalam pergaulan yang salah yang mendorong remaja tersebut untuk melakukan perbuatan yang negatif. Adapun beberapa fenomena yang banyak terjadi di masyarakat akibat perilaku remaja yang melakukan hubungan seksual pranikah, yaitu kehamilan yang tidak dikehendaki (unwanted pregnancy), penyakit menular seksual (PMS), seperti HIV/AIDS, dan dampak psikologis yang mendorong remaja untuk melakukan tindakan abortus untuk menyembunyikan aib.Untuk mencegah perilaku seksual yang beresiko di kalangan remaja sangat penting untuk memberikan pengetahuan mengenai kesehatan reproduksi sejak dini. Bentuk kegiatan pengabdian ini adalah kelas Yoga remaja dan pemberian edukasi tentang kesehatan reproduksi.

Berdasarkan hasil kegiatan program pengabdian masyarakat yang berupa Edukasi Kesehatan Remaja dan Penyakit Menular Seksual di SMK Kesehatan Sadewa Yogyakarta, didapatkan peningkatan pengetahuan siswa siswinya sebanyak 41 (91.48\%). Yoga juga mampu membuat siswa siswi SMK Kesehatan Sadewa Yogyakarta menjadi lebih rileks dan mampu mengatur emosi mereka. Melalui Edukasi Kesehatan Remaja dan Penyakit Menular Seksual dan Yoga diharapkan mampu membuat siswa-siswi menjadi sadar akan kesehatan reproduksinya dan mulai menerapkan hidup sehat dengan yoga.
\end{abstract}

KATA KUNCI Edukasi; Kesehatan Reproduksi;Yoga.

ABSTRACT Adolescence is one period of human development. This period is a turbulent period, a time full of various introductions and adventures of new things as provisions to fill their lives later. Unfortunately, many teenagers are not aware that some experiences that seem fun can actually plunge. As a result of emotions that are still unstable, not a few teenagers fall into the wrong relationships that encourage teens to do negative deeds. As for some of the phenomena that often occur in society due to the behavior of adolescents who have premarital sexual relations, namely unwanted pregnancy (unwanted pregnancy), sexually transmitted diseases (STDs), such as HIV / AIDS, and psychological effects that encourage adolescents to take abortion actions for hide disgrace.To prevent risky sexual behavior among adolescents is very important to provide knowledge about reproductive health early on. This form of community service activities is a youth Yoga class and education about reproductive health.

Based on the results of community service program activities in the form of Adolescent Health Education and Sexually Transmitted Diseases at Sadewa Health Vocational School in Yogyakarta, there was an increase in the knowledge

Budi Rahayu ........................ Edukasi Kesehatan Reproduksi dan Yoga pada Remaja 
of their students by 41 (91.48\%). Yoga is also able to make students of Yogyakarta Sadewa Health Vocational School become more relaxed and able to regulate their emotions. Through Education on Adolescent Health and Sexually Transmitted Diseases and Yoga is expected to be able to make students aware of their reproductive health and begin to implement healthy living with yoga.

KEYWORDS Education; reproduction health; Self-medication; Yoga.

\section{Pendahuluan}

Masa remaja merupakan salah satu periode dari perkembangan manusia. Masa ini merupakan masa perubahan atau peralihan dari masa kanak-kanak ke masa dewasa yang meliputi perubahan biologi, perubahan psikologi, dan perubahan sosial. Masa remaja pada umumnya di mulai pada usia 10-13 tahun dan berakhir pada usia 18-22 tahun. Masa ini adalah masa yang penuh gejolak, masa yang penuh dengan berbagai pengenalan dan petualangan akan hal-hal baru sebagai bekal untuk mengisi kehidupan mereka kelak. Sayangnya, banyak remaja yang tidak sadar bahwa beberapa pengalaman yang tampaknya menyenangkan justru dapat menjerumuskan [1].

Akibat emosi yang masih labil, tidak sedikit remaja terjerumus dalam pergaulan yang salah yang mendorong remaja tersebut untuk melakukan perbuatan yang negatif. Adapun beberapa fenomena yang banyak terjadi di masyarakat akibat perilaku remaja yang melakukan hubungan seksual pranikah, yaitu kehamilan yang tidak dikehendaki (unwanted pregnancy), penyakit menular seksual (PMS), seperti HIV/AIDS, dan dampak psikologis yang mendorong remaja untuk melakukan tindakan abortus untuk menyembunyikan aib.Untuk mencegah perilaku seksual yang beresiko di kalangan remaja sangat penting untuk memberikan pengetahuan mengenai kesehatan reproduksi sejak dini [2].

Menurut World Health Organization (WHO), kesehatan reproduksi merupakan suatu keadaan fisik, mental dan sosial yang utuh, bukan hanya bebas dari penyakit atau kecacatan dalam segala aspek yang berhubungan dengan sistem reproduksi, fungsi serta prosesnya. Kesehatan reproduksi juga dapat didefinisikan sebagai suatu keadaan dimana manusia dapat menikmati kehidupan seksualnya serta mampu menjalankan fungsi dan proses reproduksinya secara sehat dan aman [3].

Emosi Remaja yang masih labil, tidak sedikit remaja terjerumus dalam pergaulan yang salah yang mendorong remaja tersebut untuk melakukan perbuatan yang negatif. Yoga merupakan salah satu bentuk latihan tubuh menyeluruh yang hadir dari berabad masa lalu dan menjadi karunia di dunia modern kini. Selain Yoga menciptakan kesehatan fisik, berlatih yoga juga dapat menghadirkan ketenangan pikiran dan ketenangan batin. Yoga bukan sekedar aktivitas olahraga biasa, tetapi karena merupakan gaya hidup sehat yang dapat menyeimbangkan fisik, mental dan spiritual. Pada ibu hamil, berlatih yoga dapat menjadi kebiasaan baik yang dapat menetralkan berbagai ketidaknyamanan fisik, mental, dan emosi [4].

Masalah kesehatan reproduksi remaja dan pengendalian emosi remaja di Indonesia kurang mendapat perhatian yang cukup akibat pengetahuan mengenai kesehatan reproduksi seringkali masih dianggap tabu. Karena itu perlu adanya kesadaran dan peran serta dari berbagai instansi terkait untuk mampu memberikan pengetahuan mungkin mengenai pentingnya menjaga kesehatan reproduksi. Hal ini dapat dilakukan secara nyata melalui upaya penyuluhan. 


\section{Metode}

a. Tahap Persiapan

Pada tahap persiapan ini kegiatan yang dilakukan adalah:

1) Menyusun proposal kegiatan

2) Melakukan sosialisasi kegiatan kepada sasaran

3) Mempersiapkan materi dan media yang akan digunakan

b. Tahap II : Pelaksanaan

Pada tahap ini kegiatan yang dilakukan adalah:

1) Bentuk kegiatan

Bentuk kegiatan ini adalah pendidikan kesehatan mengenai kesehatan reproduksi pada remaja dan penyakit menular seksual.

2) Media dan Alat

Media yang digunakan untuk kegiatan ini adalah video yoga. Sedangkan alat yang dibutuhkan adalah matras (yoga mat), video player, layar, sound system.

3) Peserta

Siswa kelas XII sejumlah 54 siswa

4) Waktu pelaksanaan

Bulan November Minggu ke dua tahun 2019

5) Tempat pelaksanaan

Sekolah Menengah Kesehatan Sadewa Yogyakarta

6) Tahapan kegiatan

a) pretest tentang kesehatan reproduksi.

b) Pemberian materi tentang kesehatan reproduksi dan penyakit menular seksual

c) posttest tentang kesehatan reproduksi dan penyakit menular seksual

d) Latihan yoga

e) Pendinginan dengan melakukan relaksasi pada peserta.

c. Tahap III : Evaluasi dan Pelaporan

Pada tahap ini kegiatan yang dilakukan adalah:

1) Mengevaluasi hasil kegiatan.

Melihat kemampuan siswa dalam melakukan gerakan-gerakan dalam latihan yoga

2) Menyusun laporan hasil kegiatan

\section{Hasil}

Data tingkat pengetahuan peserta sebelum dan setelah intervensi atau pemberian materi dapat dilihat pada Gambar 1. Hasil pretest rata-rata hasil rendah, namun setelah pemberian materi terdapat peningkatan tingkat pengetahuan peserta terkait edukasi kesehatan reproduksi dan penyakit menular seksual yang dapat dilihat dari nilai postest.

Edukasi merupakan sebuah metode penyampaian informasi atau penyuluhan kepada seseorang atau sekelompok masyarakat dalam rangka penigkatan pengetahuan individu maupun kelompok. Selain diberikan dalam bentuk ceramah, demonstrasi, dan praktik, responden juga diberikan media leaflet dan video di dalam pelaksanaan kegiatan. Hasil pengabdian ini menunjukkan ada kenaikan pengetahuan tentang Kesehatan Reproduksi dan penyakit Menular Seksual. Data di Gambar 2 menunjukkan terjadi kenaikan antara pretest dan posttest, kenaikan tersebut sebanyak 41 orang $(91.48 \%)$, penurunan sebanyak 2 orang $(4.25 \%)$, dan tetap sebanyak 2 orang $(4.25 \%)$. 


\section{Rekap Pretest dan Posttest Edukasi Kesehatan Reproduksi dan Penyakit Menular Seksual}

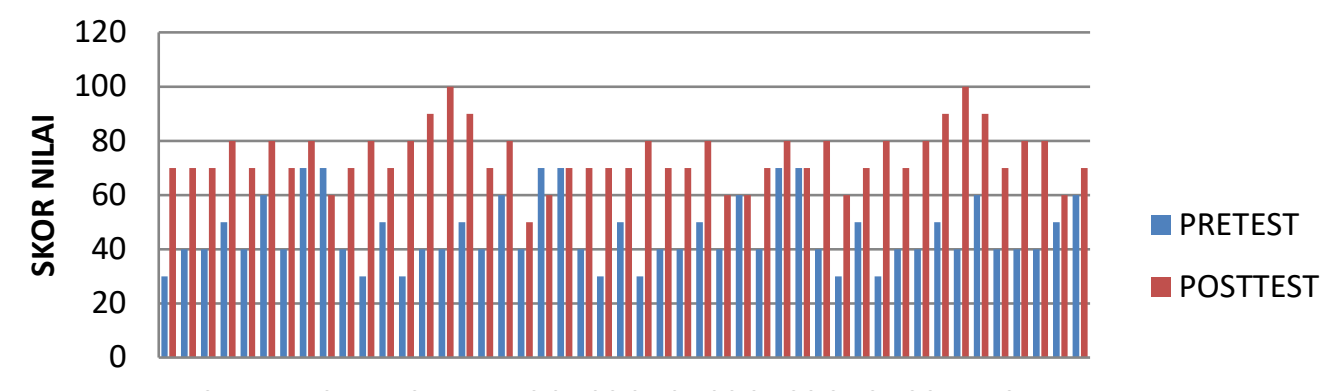

$1 \quad 3 \quad 5 \quad 7 \quad 911131517192123252729313335373941434547$ RESPONDEN

Gambar 1. Tingkat Pengetahuan Kesehatan Reproduksi Pretest dan Posttes.

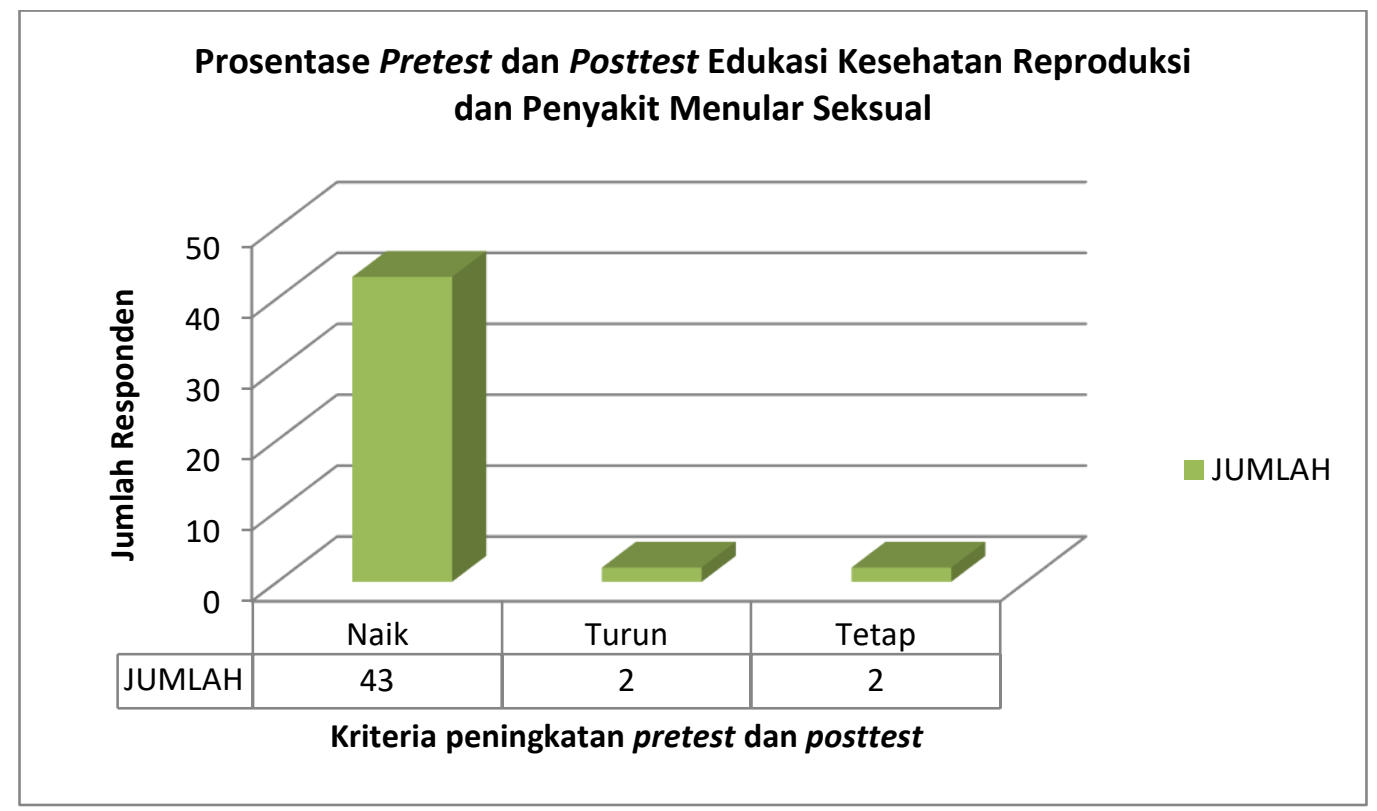

Gambar 2. Gambaran prosentase kenaikan rata-rata tingkat pengetahuan rata-rata tentang kesehatan reproduksi dan penyakit menular di smk sadewa yogyakarta

Kemudian evaluasi kegiatan dilakukan dengan memberikan kuisioner kepada peserta. Kuisioner yang diberikan berisi pertanyaan terkait materi dan media yang diberikan serta kinerja para pemateri dalam menyampaikan materi kepada peserta. Dari hasil yang di Gambar 3. menunjukkan sebagian besar peserta merasa puas dengan kegiatan ini. 


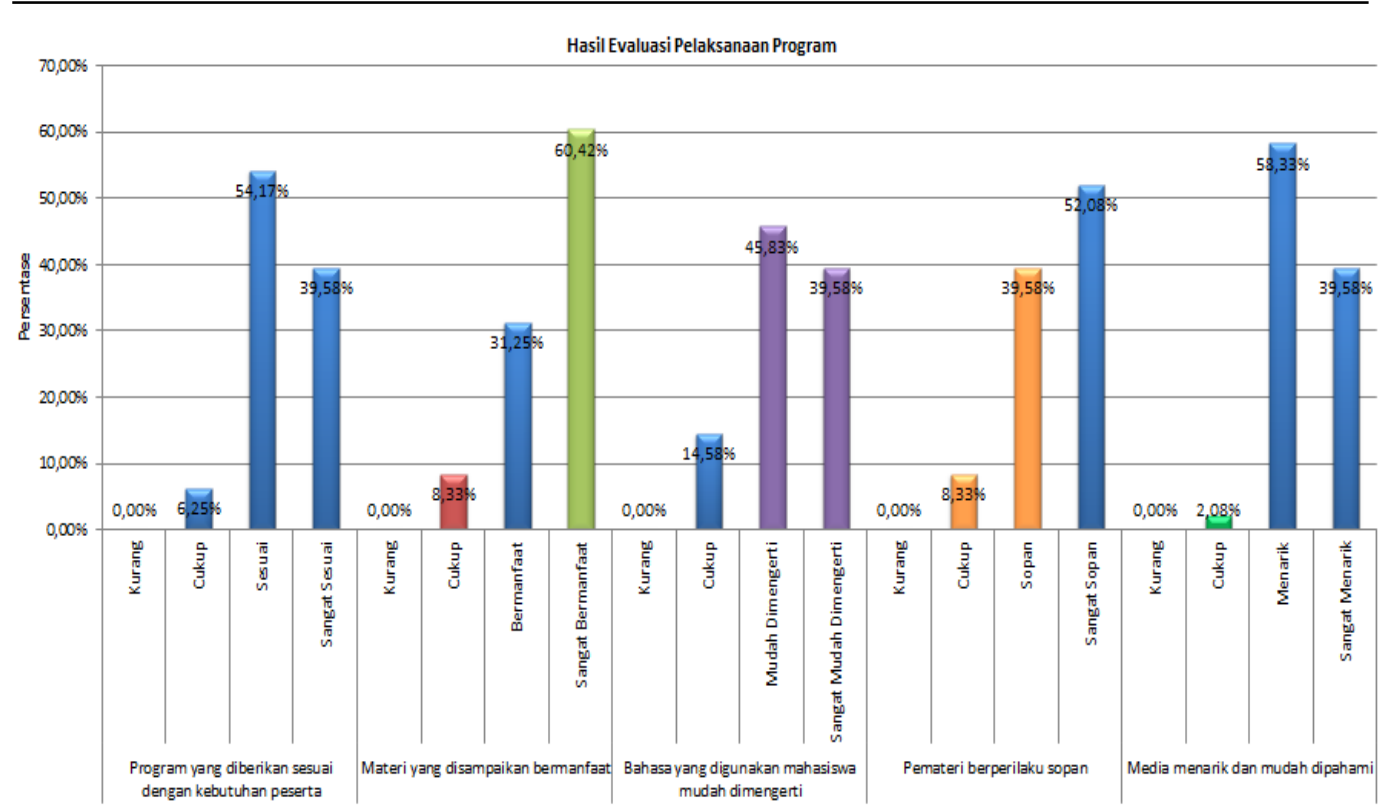

Gambar 3. Hasil evaluasi pelaksanaan program

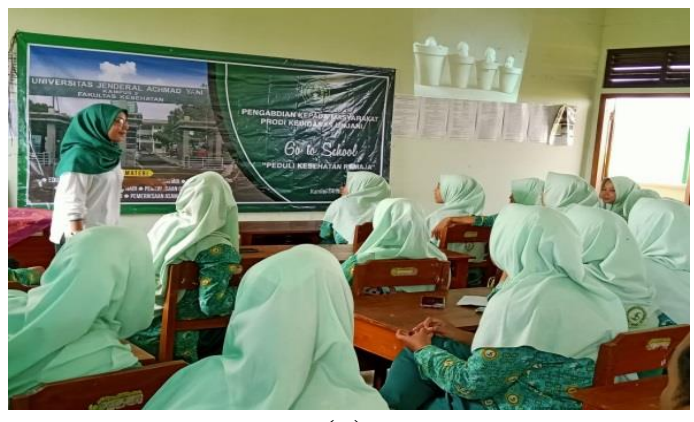

(a)

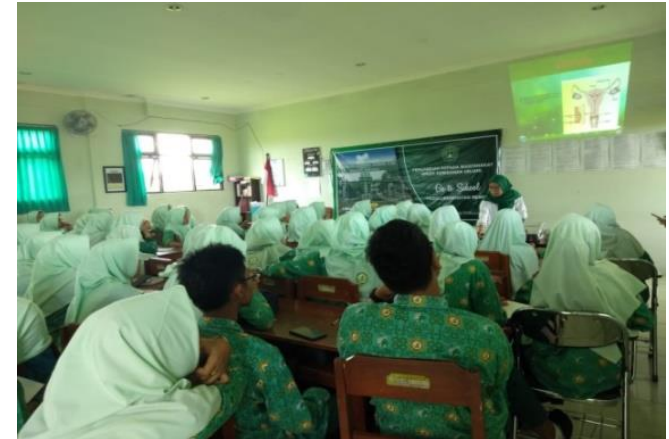

(c)

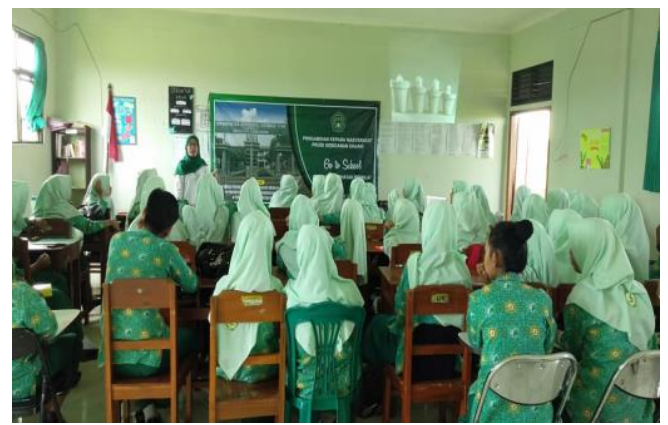

(b)

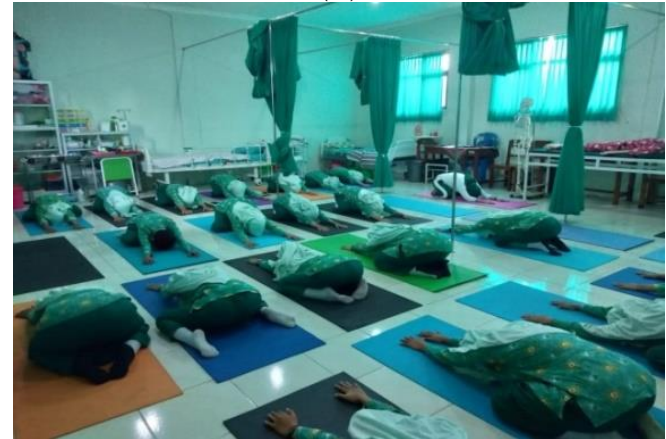

(d)

Gambar 7. Pretest (a), Penyampaian materi (b), Postest (c), Kelas Yoga (d)

\section{Pembahasan}

Rencana kegiatan pertama adalah pretest dilakukan dikelas dengan jumlah siswa yang hadir pada saat itu 48. Kuesioner dibagikan dan diberikan waktu 10-15 menit untuk mengerjakan soal pretest. Setelah siswa siswi selesai mengerjakan soal pretest kemudian diberikan edukasi mengenai Kesehatan reproduksi dan penyakit menular seksual berikut juga tanya jawab dengan peserta pengabdian kepada masyarakat. Edukasi telah selesai dilakukan langkah selanjutnya yaitu diberikan postest untuk mengetahui sejauh mana siswa-siswi paham mengenai Kesehatan reproduksi dan penyakit menular seksual.

Edukasi merupakan sebuah metode penyampaian informasi atau penyuluhan kepada seseorang atau sekelompok masyarakat dalam rangka penigkatan pengetahuan individu maupun kelompok. Selain diberikan dalam bentuk ceramah, 
demonstrasi, dan praktik, responden juga diberikan media leaflet dan video di dalam pelaksanaan kegiatan. Hasil pengabdian ini menunjukkan ada kenaikan pengetahuan tentang Kesehatan Reproduksi dan penyakit Menular Seksual. Data di atas menunjukkan terjadi kenaikan antara pretest dan posttest, kenaikan tersebut sebanyak 41 orang $(91.48 \%)$, penurunan sebanyak 2 orang $(4.25 \%)$, dan tetap sebanyak 2 orang (4.25\%).

Yoga remaja ini dilaksanakan sebanyak 2 sesi karena kapasitas ruangan yang hanya memungkinkan diisi sebanyak 25 orang. setiap sesi berlangsung selama 90 menit. Langkah-langkah yoga diantaranya

a. Warming up di berikan afirmasi positif untuk kegiatan yoga pada pagi hari.

b. Gerakan Sukhasana Ini gerakan paling dasar dari yoga. Hanya perlu duduk bersila di atas matras dan letakkan kedua tangan di atas lutut. Tarik napas perlahan dan lepaskan. Gerakan Sukhasana bisa meredakan stres dan memberikan ketenangan pada tubuh

c. Gerakan Bujang Cobra (Bhujang Asana). Gerakan ini bisa membuat perut jadi lebih kencang dan dapat menguatkan serta melenturkan otot tulang belakang. Gerakan ini dilakukan dengan berbaring tengkurap, letakkan tangan sejajar dengan pundak. Lalu posisikan dagu di lantai dan jari-jari kaki bertumpuk pada lantai. Kemudian tarik napas dan angkat dada dengan bertumpu pada kedua tangan.

d. Gerakan Upward dan Downward Facing Dog. Gerakan ini bagus dilakukan untuk pemula yang ingin memperkuat

e. otot tangan, perut, kaki, lengan serta tulang belakang. Gerakan ini dimulai dengan posisi tubuh telungkup, lalu angkat tubuh lebih tinggi dengan kekuatan kaki dan tangan. Namun pastikan posisi tangan dan kaki sejajar dengan punggung menghadap ke atas sehingga membentuk posisi busur. Tahan gerakan ini sebanyak 5-10 hitungan sembari mengatur pernapasan.

f. Child Pose. Untuk melakukan gerakan Child Pose ini, pertama-tama Ibu bisa melakukannya dengan mengambil posisi duduk bersimpuh, lalu condongkan badan ke depan hingga paha dan kepala bisa menyentuh lantai. Lalu, julurkan tangan ke depan dan hitung selama beberapa detik. Tutup mata Ibu dan tarik nafas dalam-dalam, tahan selama kurang lebih dua menit. Gerakan yoga untuk pemula ini sangat simpel namun Ibu akan merasakan efek yang lebih banyak daripada gerakan sebelumnya, yakni melatih alat pernapasan, sebagai peregangan pinggul, paha depan dan punggung.

g. Gerakan Yoga Wind Relieve (Pavanamukthasana). Untuk melancarkan pencernaan, kita bisa melakukan gerakan yoga wind relieve atau yang sering disebut dengan Pavanamukhuthasana. Caranya adalah dengan berbaring terlentang, angkat kaki ke arah perut, tekuk lutut dan peluk dengan kedua tangan. Tahan gerakan yoga ini selama 10-15 detik.

h. Back Pain Pose. Gerakan ini sangat berguna untuk melatih otot punggung dan membantu menyembuhkan cedera pada otot punggung. Gerakan ini diawali dengan tidur telentang, lalu tekuklah kaki sambil mengangkat pantat secara perlahan hingga membentuk sudut 450 . Letakkan tangan di samping kiri dan kaki dalam posisi yang rileks. Gerakan Back Pain Pose ini berguna untuk membuat posisi tulang menjadi lurus dan tegak serta mencegah tubuh bungkuk, karena tulang belakang dilatih dengan cara ditekuk berlawanan arah dengan kebiasaan kita sehari-hari. 
i. Gerakan Tree Pose. Gerakan yoga satu ini dapat dilakukan dengan berdiri tegak, lalu angkat kaki kanan dan lipat ke arah depan kaki kiri. Tahan selama 30 detik dan kemudian ganti dengan kaki satunya lagi. Gerakan yoga ini dapat memberikan keseimbangan pada tubuh.

j. cool down dan diberikan afirmasi positif untuk remaja.

Hasil setelah sesi pertama dan kedua selesai, beberapa peserta dengan random sampling memperagakan lagi gerakan yoga dari awal sampai dengan selesai, dan gerakan mereka benar. dan secara kualitatif mereka merasakan segar dan rileks kerana saat yoga diberikan afirmasi positif sehingga mereka merasa bisa mengendalikan emosi dan bisa rileks.

\section{Kesimpulan}

Berdasarkan hasil kegiatan program pengabdian masyarakat yang berupa Edukasi Kesehatan Remaja dan Penyakit Menular Seksual di SMK Kesehatan Sadewa Yogyakarta, didapatkan peningkatan pengetahuan siswa siswinya. Yoga juga mampu membuat siswa siswi SMK Kesehatan Sadewa Yogyakarta menjadi lebih rileks dan mampu mengatur emosi mereka. Melalui Edukasi Kesehatan Remaja dan Penyakit Menular Seksual dan Yoga diharapkan mampu membuat siswa-siswi menjadi sadar akan kesehatan reproduksinya dan mulai menerapkan hidup sehat dengan yoga.

\section{Ucapan terima kasih}

Dalam kesempatan ini ucapan terima kasih kami tujukan kepada Kuswanto Hardjo, dr., M.Kes. selaku Dekan Fakultas Kesehatan Universitas Jenderal Achmad Yani Yogyakarta, Deby Zulkarnain, R.S, S.Kep., Ns., MMR. selaku Ketua PPPM Fakultas Kesehatan Universitas Jenderal Achmad Yani Yogyakarta, Melisa Putri Rahmadenia, S.ST., M.Clind. selaku Ketua Program Studi Kebidanan (S-1) Universitas Jenderal Achmad Yani Yogyakarta, Kepala Sekolah dan para dewan guru Sekolah menengah Kesehatan Sadewa Yogyakarta

\section{Daftar pustaka}

[1] Sindhu Pujiastuti, 2012. Yoga untuk kehamilan sehat, bahagia, penuh makna. Bandung.

[2] Kementrian Kesehatan RI. 2015. Kesehatan Reproduksi dan seksual Bagi Calon Pengantin. Jakarta : Kemenkes RI.

[3] Kementerian Kesehatan RI. 2017. Buku Saku Remaja pada Situasi Krisis Kesehatan. Jakarta : Kemenkes RI.

[4] UU Kesehatan No. 36 Tahun 2009.

[5] PP No. 61 Tahun 2014 Tentang Kesehatan Reproduksi. 